\title{
The State and Dynamics \\ of Biological Communities in the Rybinsk Reservoir under Climate Changes
}

\author{
Ludmila G. Korneva*, Valentina I. Lazareva, \\ Natalia M. Mineeva, Lubov E. Sigareva, \\ Eugenia A. Sokolova, Natalia A. Timofeeva, \\ Irina V. Mitropol'skya and Vera V. Solovyeva \\ Papain Institute for Biology of Inland Waters RAS \\ Borok, Yaroslavl oblast, 152742, Russia
}

Received 14.03.2016, received in revised form 21.07.2016, accepted 09.04.2017, published online 01.02.2018

The long-term data on structural characteristics of phytoplankton (1954-2014) and zooplankton (2004-2013), as well as chlorophyll content in the water and bottom sediments (2009-2014) in the Rybinsk Reservoir (Upper Volga, Russia) were analyzed. It was shown that the modern climate changes lead to transformation in the state and dynamics of biological communities that is characteristic of the trophicity increase. After the abnormally hot summer of 2010 a sharp rise in chlorophyll content in water with a predominance of values typical for eutrophic and highly eutrophic conditions was detected. Distribution of plant pigments in the bottom sediments was similar in different years, which shows the specific character of the sediment complex structure in the reservoir. In the seasonal dynamics of phytoplankton biomass and chlorophyll concentration the summer maximum caused by development of cyanobacteria began to dominate above the spring one. In the structure of phytoplankton the proportions of cyanobacteria and myxotrophic phytophagellates increased, the invasion of brackish-water diatoms was marked, and diminution of the cell size was noted. In seasonal dynamics of zooplankton biomass the second late peak was formed in August and it was particularly pronounced in the abnormally hot summer of 2010. In addition, there was a 1-2 week shift in timing of the beginning and ending in seasonal cycle of a number of zooplankton species relative to the 1960-1970s. Appearance of a summer dissolved oxygen deficiency (up to $1-4 \mathrm{mg} \mathrm{O}_{2} / \mathrm{L}$ in the layer of 1-7 $\mathrm{m}$ above the bottom) resulted in a local change in the vertical distribution of crustacean filtrators and decrease in their abundance up to three times.

Keywords: phytoplankton, chlorophyll, zooplankton, community structure and dynamics, climate changes, Rybinsk Reservoir, Upper Volga.

(c) Siberian Federal University. All rights reserved

* Corresponding author E-mail address: korneva@ibiw.yaroslavl.ru 
Citation: Korneva L.G., Lazareva V.I., Mineeva N.M., Sigareva L.E., Sokolova E.A., Timofeeva N.A., Mitropol'skya I.V., Solovyeva V.V. The state and dynamics of biological communities in the Rybinsk Reservoir under climate changes. J. Sib. Fed. Univ. Biol., 2019, 12(2), 160-179. DOI: 10.17516/1997-1389-0037.

\title{
Состояние и динамика биологических сообществ Рыбинского водохранилища
}

в условиях изменения климата

\author{
Л.Г. Корнева, В.И. Лазарева, \\ Н.М. Минеева, Л.Е. Сигарева, Е.А. Соколова, \\ Н.А. Тимофеева, И.В. Митропольская, В.В. Соловьева \\ Институт биологии внутренних вод им. И.Д. Папанина РАН \\ Россия, 152742, Ярославская обл., пос. Борок
}

На основе анализа многолетних данных по структурным характеристикам фито- (19542014 г2.) и зоопланктона (2004-2013 гг.), а также содержанию хлорофилла в воде и донных отложениях (2009-2014 гг.) Рыбинского водохранилища (Верхняя Волга, Россия) показано, что современные климатические изменения приводят к трансформации состояния и динамики биологических сообществ водохранилища, характерной при увеличении трофии пресноводных экосистем. После аномально жаркого лета 2010 г. выявлен резкий подъем концентрации хлорофилла в воде с преобладанием величин, характерных для эвтрофных и высокоэвтрофных вод. Распределение растительных пигментов в донных отложениях в разные годы было сходным и отражало характерную для водохранилища спеиифику структуры грунтового комплекса. В сезонной динамике биомассы фитопланктона и концентрации хлорофилла летний максимум, обусловленный развитием ичианобактерий, стал доминировать над весенним. В структуре фитопланктона увеличились пропоричи циианобактерий и миксотрофных фитофлагеллят, отмечены инвазии солоновато-водных диатомовых и уменьшение размеров клеток. В сезонной динамике биомассы зоопланктона сформировался второй позднелетний (август) пик, максимально проявившийся в аномально жаркое лето 2010 г. Кроме того, наблюдалось смещение на одну-две недели сроков начала и окончания сезонного ичикла ряда видов зоопланктона относительно 1960-1970-хгг. Появление летнего дефицита растворенного кислорода ( $\mathrm{O}_{2}$ 1-4 мг/л в слое 1-7 м над дном) привело к локальному изменению вертикального распределения ракообразных-фильтраторов и снижению их обилия до трех раз.

Ключевые слова: фитопланктон, хлорофилл, зоопланктон, структура и динамика сообществ, изменение климата, Рыбинское водохранилище, Верхняя Волга.

\section{Введение}

Глобальное потепление климата стало главной экологической проблемой в послед- ние десятилетия (Magnuson et al., 2000). Под пристальным вниманием находится связь климатических изменений с внутриводо- 
емными (в том числе биологическими) процессами (Нестеров, 2013; Adrian et al., 2009). Основные последствия современной трансформации климата в водоемах европейской части РФ проявляются в повышении температуры воды и увеличении количества осадков над водосборной площадью бассейнов с середины 1970-х гг. ХХ в., что согласуется с динамикой индексов Северо-Атлантического колебания (NAO - North Atlantic Oscillation) (Второй оценочный..., 2014). Это привело к увеличению стока Волги, подъему уровня Каспия и увеличению температуры воды в различных водохранилищах (Корнева, 2015). В Рыбинском водохранилище помимо многолетнего увеличения температуры воды наблюдается повышение минерализации (Законнова, Литвинов, 2009; Литвинов и др., 2014) и содержания органического вещества, аллохтонная часть которого тесно связана с объемом водного стока (Степанова, 2015). Цветность воды увеличилась в 1,5 раза с $38 \pm 2$ в 1960-1970-х гг. до 56 \pm 3 град. Pt-Со в современный период (Лазарева, Соколова, 2013).

K важнейшим показателям состояния водных экосистем относится содержание кислорода в воде, которое сопряжено с температурным режимом и определяет условия существования гидробионтов.

До сих пор влияние климатических факторов рассматривали лишь для отдельных биотических параметров экосистемы Рыбинского водохранилища. Поэтому крайне важно обобщить уже имеющиеся современные данные для представления ответной реакции комплекса биотических показателей на изменение климата.

Цель работы - выявить изменения в структуре и динамике основных биотических параметров (фито- и зоопланктон, содержание хлорофилла в воде и донных отложениях), а также тенденции в динамике летнего кислородного режима экосистемы Рыбинского водохранилища при современном уровне потепления климата.

\section{Материалы и методы}

Рыбинское водохранилище - третье в каскаде волжских водохранилищ после Иваньковского и Угличского, расположено в подзоне южной тайги $\left(58^{\circ} 00^{\prime}-59^{\circ} 05^{\prime}\right.$ с.ш., $37^{\circ} 28^{\prime}-39^{\circ} 00^{\prime}$ в.д.) и относится к крупным, относительно мелководным водоемам замедленного водообмена (площадь зеркала 4500 км², средняя глубина 5,6 м, средний коэффициент условного водообмена 1,9 год-1) (Экологические проблемы..., 2001). Акваторию водохранилища подразделяют на четыре плеса, водные массы которых различаются по гидрофизическим и гидрохимическим показателям (Рыбинское водохранилище..., 1972). Три плеса расположены вдоль затопленного русла основных притоков - рек Волга, Молога и Шексна. Речные воды постепенно трансформируются в водную массу собственно водохранилища, занимающю его обширную озеровидную центральную часть - Главный плес.

Содержание хлорофилла $a$ в планктоне и донных отложениях оценивали на шести стандартных станциях, расположенных в Главном и Волжском плесах, в мае-октябре 20092014 гг. Концентрацию хлорофилла в толще воды определяли флуоресцентным методом на стационарном флуориметре ПФЛ-3004, изготовленном в Красноярском госуниверситете. Модификация метода основана на специфике светособирающих пигмент-белковых комплексов зеленых, диатомовых водорослей и цианобактерий. Суммарное количество хлорофилла оценивается по его содержанию у водорослей трех названных отделов (Гольд и др., 1986; Гаевский и др., 1993). Пробы отбирали метровым батометром Элгморка из трех слоев: 0-2 м (фотическая зона), 2-6 м (до 
средней глубины водохранилища) и 6 м - дно. В работе рассмотрены средние для станций концентрации хлорофилла, которые получены простым осреднением величин, измеренных в каждом слое. Параллельно из верхнего (0-2,5 см) слоя седиментов отбирали пробы донных отложений. Растительные пигменты в них определяли спектрофотометрическим методом в общем ацетоновом экстракте. Хлорофилл $а$ и феопигменты рассчитывали по формулам Лоренцена (Lorenzen, 1967) с некоторыми модификациями (Сигарева, 2012).

Для анализа структурных характеристик фитопланктона использовали материалы многолетних наблюдений на шести стандартных станциях с 1954 по 2014 г. и расширенной сетке станций (15-25 станций) с 1995 по 2010 г. Отбор проб осуществляли из столба воды 0 м - дно, концентрирование - методом прямой фильтрации при слабом давлении поочередно через мембранные фильтры диаметром пор 3-5 мкм и 1,2-1,5 мкм, фиксацию раствором Люголя с добавлением формалина, ледяной уксусной и хромовой кислот (Методика..., 1975). Учет численности водорослей проводили в счетной камере «Учинская-2» объемом 0,01 или 0,02 мл. Биомассу определяли счетно-весовым методом (Корнева, 2015).

Для анализа зоопланктона использовали регулярные сборы (2004-2013 гг.) на шести стандартных станциях, а для оценки его пространственного распределения привлекали материалы летних (1-5 раз за сезон) маршрутных съемок в те же годы по всей акватории водоема (15-25 станций). В первом случае пробы отбирали большим (10 л) планктобатометром системы Дьяченко-Кожевникова послойно с интервалом 2 м с последующим объединением сборов в одну пробу. Во втором - малой сетью Джеди с диаметром входного отверстия 12 см и ситом с диагональю ячеи 105-115 мкм тотально от дна до поверхности. Вертикаль- ное распределение зоопланктона исследовали локально на 3-5 станциях в 2013 и 2016 гг,, пробы отбирали планктобатометром (10 л) с 2-3 горизонтов. Сборы фиксировали 4\%-ным формалином и просматривали в лаборатории в камере Богорова под микроскопами МБС-10 и StereoDiscovery-V12, схема камеральной обработки принята по (Лазарева, 2010).

Прозрачность воды измеряли по белому диску Секки, вертикальные профили температуры и кислорода с шагом 1 м определяли с помощью ручного зонда YSI-85 (YSI Inc. USA).

Значимость факторов среды для характеристик планктона оценивали с помощью регрессионного анализа (методом пошаговой регрессии) по критерию Фишера $(F)$ и частному коэффициенту детерминации $\left(R^{2}\right)$. Для оценки трофического статуса экосистемы по зоопланктону рассчитывали коэффициент трофии $E$ Мяэметса (Мяэметс, 1980) и показатель трофии $E / O$ (Hakkari, 1972) для набора видов, которые формировали не менее 5 \% численности ракообразных или коловраток, а также учитывали встречаемость представителей рода Brachionus (\%) (Андроникова, 1996).

\section{Результаты}

2004-2014 гг. относились к многоводной фазе гидрологического цикла, который характеризовался большим объемом притока речных вод (в среднем 34,41 км ${ }^{3}$ в год) и преимущественно высоким (среднее за майоктябрь >101 м БС) уровнем наполнения водохранилища (Законнова, Литвинов, 2016). Только в 2014 г. приток был аномально низким (17,4 км ${ }^{3}$ в год) с крайне низким летним уровнем водохранилища (<100,3 м БС).

К 2015 г. в водохранилище зарегистрировано значимое повышение температуры (T) воды в поверхностном горизонте летом $\left(0,9^{\circ} \mathrm{C}\right.$ 
в июле-августе) и осенью $\left(0,7^{\circ} \mathrm{C}\right.$ в октябре $)$ по сравнению с нормой (1947-1975 гг.). Средняя скорость ее увеличения для безледного периода составила $0,76{ }^{\circ} \mathrm{C} / 10$ лет, а максимальная (июль) $-1{ }^{\circ} \mathrm{C} / 10$ лет (Законнова, Литвинов, 2016). Продолжительность периода, свободного ото льда, возросла на 20 сут преимущественно за счет более поздних сроков начала ледостава (конец ноября). Во все годы с 2004 по 2014 средняя за май-октябрь Т поверхности воды $\left(15,2 \pm 0,2{ }^{\circ} \mathrm{C}\right)$ превышала норму $\left(14,2^{\circ} \mathrm{C}\right)$ для периода 1976-2014 гг. (Законнова, Литвинов, 2016). В разные годы степень прогрева водной толщи водохранилища была не одинакова. Наиболее теплыми (средняя Т поверхности воды за май-октябрь $\geq 16^{\circ} \mathrm{C}$ ) оказались 2010, 2011 и 2013 гг., близкий к норме прогрев отмечен в 2008 г. $\left(14,3 \pm 0,6^{\circ} \mathrm{C}\right)$. Аномально жарким летом 2010 г. максимальная Т поверхности воды $\left(27,9^{\circ} \mathrm{C}\right)$ на $7,6^{\circ} \mathrm{C}$ превышала таковую в 2008 г.

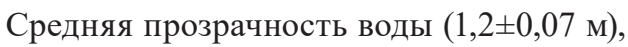
которая служит показателем подводных световых условий, была близка к наблюдавшейся до 1976 г. (до начала потепления) $(1,4 \pm 0,04$ м) (Романенко, 1985). Однако отмечено резкое снижение минимальной прозрачности летом в период массового развития планктона с $1,0 \pm 0,02$ в 2004-2009 гг. до 0,5 $\pm 0,05$ м в 20102014 гг., что могло отрицательно влиять на фотосинтез водорослей.

До начала потепления в открытой части водохранилища недостаток растворенного $\mathrm{O}_{2}$ летом обнаруживали крайне редко (Рыбинское водохранилище..., 1972). Впервые тотальное ухудшение летнего кислородного режима зарегистрировано в аномально жаркое лето 2010 г., когда Т воды у дна достигала $25{ }^{\circ} \mathrm{C}$. В последующие пять лет процесс развивался по пути увеличения слоя воды с недостатком $\mathrm{O}_{2}$. Летом 2011-2015 гг. обнаруживали снижение $\mathrm{O}_{2}<4$ мг/л ( $<50 \%$ насыщения) в слое 1-2 м над дном на $>50$ \% точек отбора проб при прогреве придонных вод до $18-19{ }^{\circ} \mathrm{C}$. Наиболее мощный слой (1-7 м над дном) с $\mathrm{O}_{2} 1-4$ мг/л почти ежегодно в июле-августе регистрировали в озеровидной части водохранилища вдоль затопленного русла рек Волги, Мологи и Шексны, обычно в течение 2 нед., на отдельных участках - 1-3 мес.

Исследования фитопланктона Рыбинского водохранилища на шести стандартных станциях с 1954 по 1981 г. показали, что его сезонная динамика характеризовалась тремя подъемами биомассы - весной, летом и осенью - и обусловлена развитием диатомовых водорослей (рис. 1). В летний период к ним присоединялись цианобактерии. До 1977 г. в сезонной периодичности фитопланктона водохранилища был хорошо выражен весенний максимум диатомей (Корнева, 2015). С 1977 г. летний пик начал достигать весеннего максимума за счет интенсивного развития цианобактерий и потом даже превышать его. После достоверного увеличения суммарной биомассы фитопланктона с 1954 по 1999 г. в последнее десятилетие она стала заметно снижаться. В 1954-1999 гг. ее среднее многолетнее значение составляло $1,91 \pm 0,13 \Gamma / \mathrm{M}^{3}$, а в

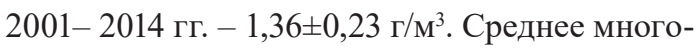
летнее соотношение численности и биомассы $\left(\mathrm{x} 10^{-3}\right)$, как показателя размерности клеток, в 1954-1981 гг. составляло 6,84 $\pm 0,48$, а в 20012014 гг. $-9,07 \pm 0,46$. В соотношении основных таксономических групп фитопланктона в последние два десятилетия произошли существенные изменения: в биомассе значительно увеличилась доля цианобактерий и снизилась таковая диатомовых (табл. 1). Помимо этого, в структуре планктонного сообщества Рыбинского водохранилища наблюдалось увеличение пропорции миксотрофных фитофлагеллят (Korneva, Solovyeva, 2017) и, прежде всего, криптофитовых водорослей (Корнева, 

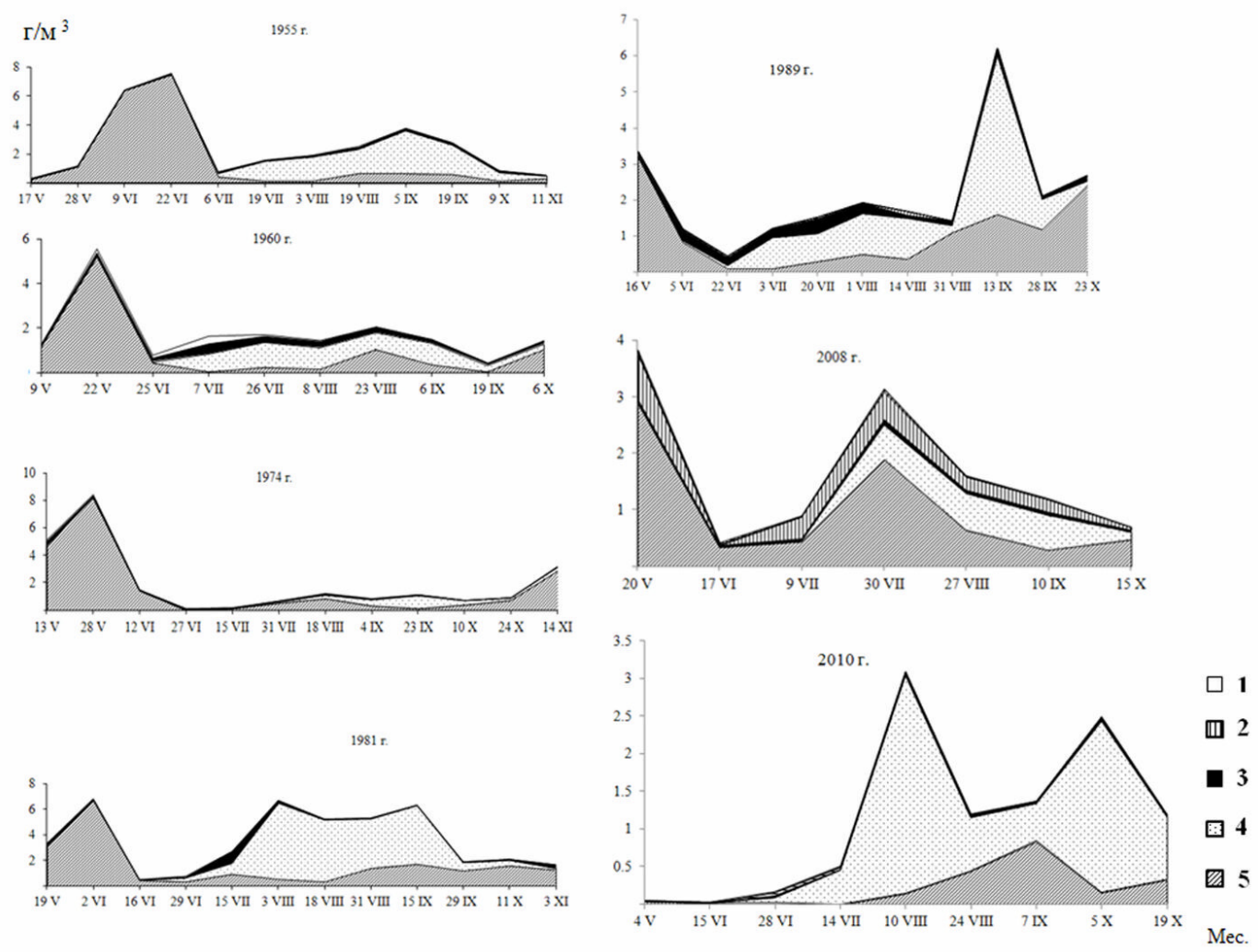

Рис. 1. Сезонная динамика биомассы фитопланктона Рыбинского водохранилища в разные годы: 1 прочие; 2 - криптофитовые; 3 - зеленые; 4 - цианобактерии; 5 - диатомовые

Fig. 1. Seasonal dynamics of phytoplankton biomass in the Rybinsk Reservoir in different years: 1 - others; 2 cryptophytes; 3 - greens; 4 - cyanobacteria; 5 - diatoms

Таблица 1. Изменение биомассы $\left(г / \mathbf{M}^{3}\right)$ диатомовых водорослей и цианобактерий в Рыбинском водохранилище в 1954-2014 гг.

Table 1. Change in biomass $\left(\mathrm{g} / \mathrm{m}^{3}\right)$ of diatoms and cyanobacteria in the Rybinsk Reservoir during 1954-2014

\begin{tabular}{|c|c|c|c|c|}
\hline \multirow{2}{*}{ Годы } & \multicolumn{2}{|c|}{ Диатомовые } & \multicolumn{2}{c|}{ Цианобактерии } \\
\cline { 2 - 5 } & Биомасса & \% от общей & Биомасса & \% от общей \\
\hline $1954-1989$ & $1,25 \pm 0,09$ & 68 & $0,47 \pm 0,07$ & 24 \\
\hline $1996-2014$ & $0,33 \pm 0,07$ & 25 & $1,08 \pm 0,02$ & 65 \\
\hline
\end{tabular}

2015). Кроме того, обнаружено появление и распространение эвригалинных чужеродных видов диатомовых водорослей: Skeletonema subsalsum (Cleve-Euler) Bethge и Actinocyclus normanii (Gregory ex Greville) Hustedt.

По данным 1954-1981 гг. получена достоверная отрицательная связь биомассы фитопланктона с уровнем и положительная ее связь с температурой воды (Корнева, 2015). В 1969-2010 гг. наиболее тесная корреляция с температурой воды $(R=0,81, F=51)$ прослеживалась у цианобактерий.

За период исследования 2009-2014 гг. суммарное содержание хлорофилла $a$ ( $\Sigma \mathrm{X} л)$ в воде водохранилища изменялось на три порядка величин (табл. 2). Концентрации менее 
Таблица 2. Содержание хлорофилла в Рыбинском водохранилище в различные годы (над чертой пределы, под чертой средние со стандартной ошибкой; $n$ - число наблюдений)

Table 2. Chlorophyll concentration in Rybinsk Reservoir in different years (above the line -limits, below the line - average values with standard error; $n$ - number of observations)

\begin{tabular}{|c|c|c|c|c|c|c|c|c|}
\hline \multirow{2}{*}{ Год } & \multirow{2}{*}{$n$} & \multirow{2}{*}{$\Sigma$ Хл, мкг/л } & \multicolumn{2}{|c|}{ Хл$\pi_{\text {Cyan }}$} & \multicolumn{2}{|c|}{ Хл $л_{\text {Bac }}$} & \multicolumn{2}{|c|}{$\mathrm{X}_{\mathrm{Chl}}$} \\
\hline & & & мкг/Л & $\%$ & мкг/л & $\%$ & мкг/л & $\%$ \\
\hline \multirow[t]{2}{*}{2009} & 189 & $0,0-25,9$ & $\underline{0,0-25,1}$ & $\underline{0,0-99,2}$ & $\underline{0,0-18,4}$ & $\underline{0,0-100}$ & $\underline{0,0-0,7}$ & $\underline{0,0-7,0}$ \\
\hline & & $7,7 \pm 0,4$ & $5,2 \pm 0,4$ & $61,0 \pm 1,9$ & $2,4 \pm 0,2$ & $36,1 \pm 1,7$ & $0,1 \pm 0,0$ & $3,0 \pm 0,6$ \\
\hline \multirow[t]{2}{*}{2010} & 172 & $\underline{0,1-73,3}$ & $\underline{0,0-32,2}$ & $\underline{0,0-93,8}$ & $\underline{0,0-66,9}$ & $\underline{5,7-99,7}$ & $\underline{0,0-3,8}$ & $\underline{0,0-36,1}$ \\
\hline & & $10,5 \pm 1,0$ & $4,6 \pm 0,5$ & $45,4 \pm 2,1$ & $5,8 \pm 0,8$ & $52,7 \pm 2,1$ & $0,1 \pm 0,0$ & $2,4 \pm 0,3$ \\
\hline \multirow[t]{2}{*}{2011} & 202 & $\underline{0,6-146}$ & $\underline{0,1-132}$ & $\underline{0,8-100}$ & $\underline{0,0-92,0}$ & $\underline{0,0-98,9}$ & $\underline{0,0-16,4}$ & $\underline{0,0-12,6}$ \\
\hline & & $23,0 \pm 1,7$ & $14,9 \pm 1,2$ & $57,9 \pm 2,1$ & $7,6 \pm 0,9$ & $40,1 \pm 2,0$ & $0,5 \pm 0,2$ & $2,1 \pm 0,2$ \\
\hline \multirow[t]{2}{*}{2012} & 203 & $\underline{0,9-69,4}$ & $\underline{0,4-63,8}$ & $\underline{8,5-96,7}$ & $\underline{0,3-31,5}$ & $\underline{3,2-89,9}$ & $\underline{0,0-1,0}$ & $\underline{0,0-15,5}$ \\
\hline & & $17,6 \pm 0,8$ & $11,0 \pm 0,7$ & $59,5 \pm 1,4$ & $6,5 \pm 0,4$ & $39,6 \pm 1,4$ & $0,1 \pm 0,0$ & $0,9 \pm 0,1$ \\
\hline \multirow[t]{2}{*}{2013} & 227 & $\underline{0,3-107}$ & $\underline{0,0-101}$ & $\underline{1,7-99,9}$ & $\underline{0,0-30,2}$ & $\underline{0,0-94,5}$ & $\underline{0,0-4,3}$ & $\underline{0,0-28,0}$ \\
\hline & & $25,0 \pm 1,4$ & $19,5 \pm 1,3$ & $67,0 \pm 1,7$ & $5,1 \pm 0,3$ & $30,9 \pm 1,6$ & $0,3 \pm 0,0$ & $2,1 \pm 0,2$ \\
\hline \multirow[t]{2}{*}{2014} & 125 & $\underline{0,8-136}$ & $\underline{0,1-135}$ & $\underline{0,9-99,7}$ & $\underline{0,2-46,2}$ & $\underline{0,2-97,3}$ & $\underline{0,0-3,2}$ & $\underline{0,0-8,0}$ \\
\hline & & $19,7 \pm 1,8$ & $12,1 \pm 1,7$ & $57,0 \pm 2,6$ & $7,4 \pm 0,8$ & $41,6 \pm 2,6$ & $0,2 \pm 0,0$ & $1,5 \pm 0,1$ \\
\hline
\end{tabular}

1-3 мкг/л составили $~ 14 \%$ общего числа наблюдений, от 10 до 30 мкг/л - 40-50\%, более высокие величины - 20 \%. Преобладающие концентрации типичны для умеренно эвтрофных и эвтрофных водоемов. Максимальные величины, отмеченные в эвфотной зоне, в 2010, 2011, 2013 и 2014 гг. превышали 100 мкг/л. Такие высокие показатели в единичных случаях регистрировались в водохранилище и раньше (Минеева, 2004).

В фонде $\Sigma$ Хл преобладал хлорофилл цианобактерий $\left(\mathrm{X}_{\text {Суап }}\right)$ и диатомовых $\left(\mathrm{X}_{\text {вас }}\right)$ водорослей (табл. 2), что согласуется с фактическим таксономическим составом фитопланктона водохранилища (Корнева, 2015). Минимальные концентрации Х $л_{\text {Суап }}$ и Х $Л_{\text {вас }}$

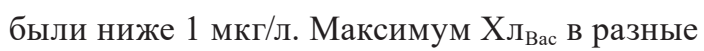
годы достигал 18,4-92,0 мкг/л, а преобладающие концентрации (85 \% величин) ограничены 10 мкг/л. Максимальные концентрации Хл $л_{\text {Суап }}$ составили 25,1-135 мкг/л при превалировании величины до 30 мкг/л (90 \%). Со- держание хлорофилла зеленых водорослей $\left(\mathrm{X}_{\mathrm{Chl}}\right)$ в основном было ниже 1 мкг/л (Минеева, 2016). Содержание $\mathrm{X}_{\text {вас }}$ составляло высокую долю $\Sigma$ Хл в период весенней (май-начало июня), а в 2014 г. - летней и осенней вспышки диатомей. Встречаемость таких ситуаций равнялась $20 \%$. В $62 \%$ случаев, обычно в июле-сентябре, в период массового развития цианобактерий, фонд $\Sigma$ Хл формировался за

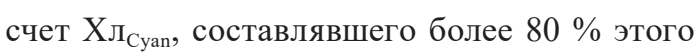
фонда. Однако с 2011 г. вклад Хл Суап стал заметным уже в начале вегетационного сезона (рис. 2). В $17 \%$ случаев, как правило, в июне при сезонной смене сообществ, а в 2010 и 2012 гг. осенью относительное содержание Хл $л_{\text {вас }}$ и Хл Суап было одинаковым.

Анализ сезонной динамики показывает, что в 2009 г. общий фонд хлорофилла был низким, в июле-сентябре отмечен незначительный летний подъем $\Sigma$ Хл за счет подъема Хл $л_{\text {суап. }}$ В 2010 г. интенсивный рост концен-

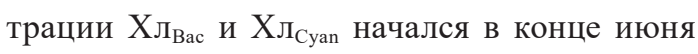


при увеличении температуры водной толщи. Однако при Т $25^{\circ} \mathrm{C}$ и более в июле содержание Хл $л_{\text {суап }}$ не превышало уровня предыдущего года, а в конце августа, когда температура воды вернулась к многолетней норме, максимум $\Sigma$ Хл был обусловлен подъемом Хл вас. В 2011 и 2012 гг. концентрации $\Sigma$ Хл существенно выросли по сравнению с двумя предшествующими годами, весенний пик в основном формировался за счет Х $л_{\text {вас }}$, летний - за счет Х⿰ $л_{\text {Суап. }}$ В 2013 г. содержание хлорофилла оставалось высоким и летний максимум значительно превысил весенний. В 2014 г. при чрезвычайно низком уровне водохранилища в сентябре-октябре единственный раз за период наблюдения был зафиксирован мощный осенний максимум $\Sigma$ Хл, превосходивший летний, при высоком содержании Х⿰ $\mathrm{Jac}_{\mathrm{Bac}}$ (рис. 2).

Растительные пигменты в донных отложениях глубоководных участков Рыбинского водохранилища находятся преимущественно ( $80 \%)$ в деградированном виде. Главные факторы содержания осадочных пигментов - продуктивность фитопланктона и условия формирования грунтового комплекса (Сигарева, 2012; Sigareva et al., 2013; Sigareva, Timofeeva, 2011, 2014). Содержание пигментов в донных отложениях водохранилища варьирует во времени и пространстве (коэффициент вариации $C_{v}=13-275 \%$ ). При этом изменчивость концентраций на станциях $\left(C_{v}=30-125 \%\right)$ выражена сильнее, чем по годам $\left(C_{v}=34-89 \%\right)$. Для участков с интенсивной циркуляцией водных масс (ст. Наволок, Измайлово) характерны низкие суммарные концентрации хлорофилла и феопигментов (Хл+Ф), значительная их вариабельность и отсутствие четко выраженной сезонной и многолетней динамики (рис. 3). На участках илонакопления концентрации пигментов (Хл+Ф) достигают высоких значений: в Волжском плесе - 431, в Главном 493 мкг/г сухого осадка. Средняя за все годы концентрация Хл+Ф (240 \pm 14 мкг/г сухого осадка) максимальна на ст. Средний Двор, где преобладают торфогенные илы. Характер распределения пигментов по станциям

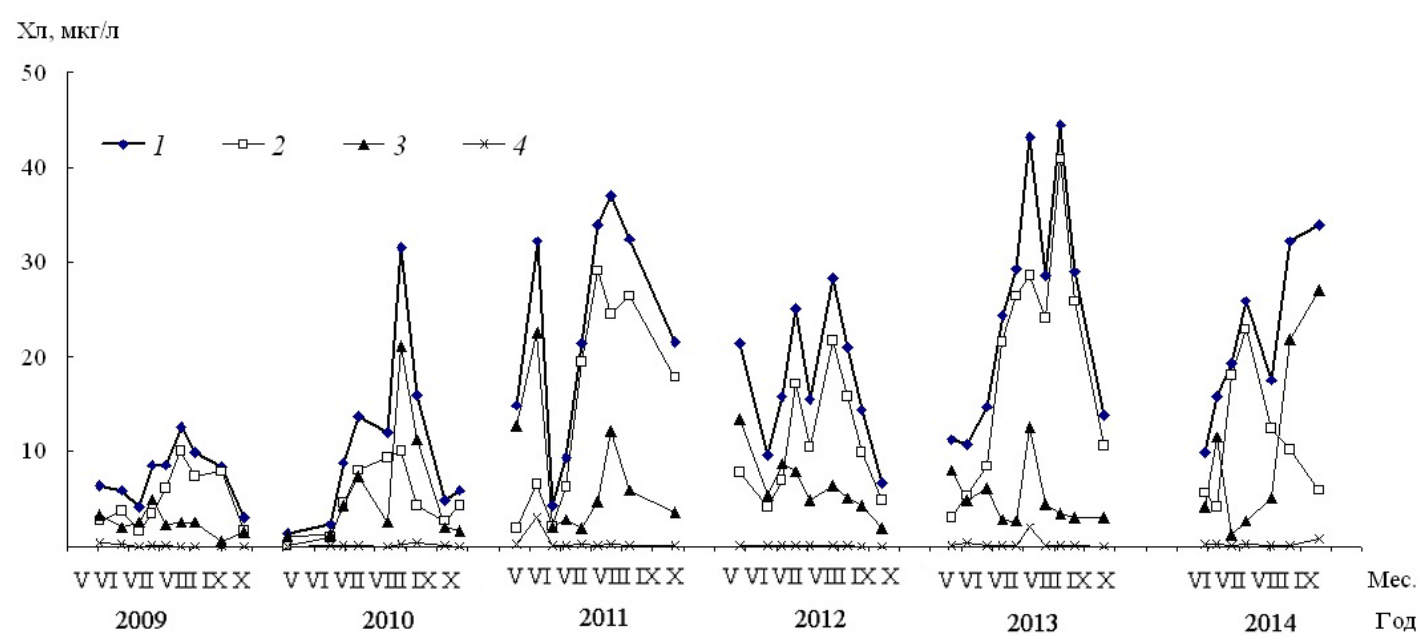

Рис. 2. Сезонная динамика хлорофилла а в планктоне Рыбинского водохранилища в 2009-2014 гг.: 1 $\Sigma$ Хл; 2 - Хл

Fig. 2. Seasonal dynamics of chlorophyll $a$ in plankton of the Rybinsk Reservoir in 2009-2014: $1-\Sigma$ Chl; $2-$ $\mathrm{Chl}_{\text {Cyan }} ; 3-\mathrm{Chl}_{\mathrm{Bac}} ; 4-\mathrm{Chl}_{\mathrm{Chl}}$ (average values) 

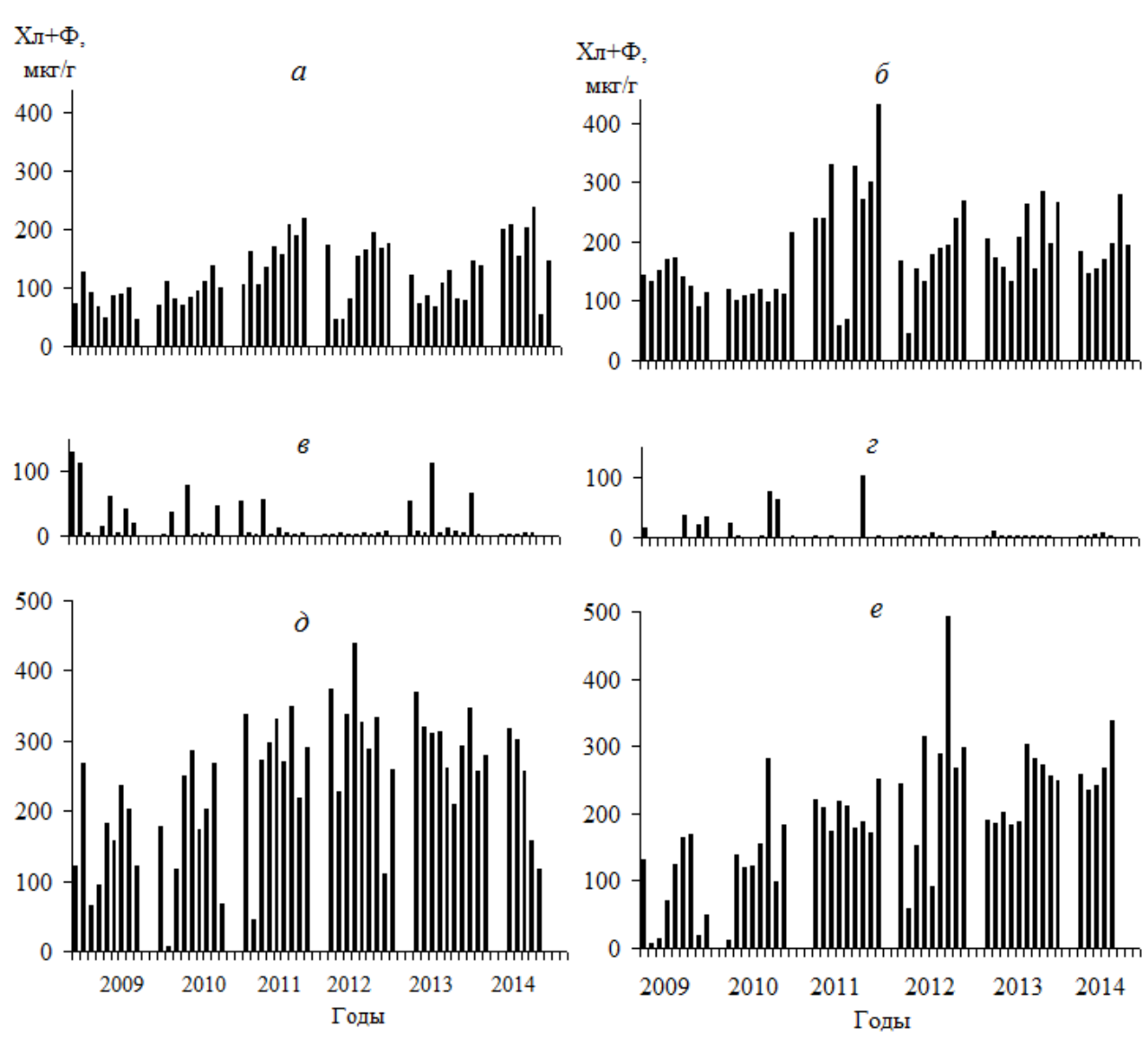

Рис. 3. Сезонная динамика концентрации растительных пигментов (хлорофилл $a$ в сумме с феопигментами, мкг/г сухого осадка) в донных отложениях на постоянных станциях Рыбинского водохранилища в безледные периоды 2009-2014 гг. Станции: $a$ - Коприно; $\sigma$ - Молога; $в$ - Наволок; 2 - Измайлово; $\partial-$ Средний Двор; $e-$ Брейтово

Fig. 3. Seasonal dynamics of plant pigments concentration (chlorophyll $a$ with pheopigments, $\mu \mathrm{g} / \mathrm{g}$ dry sediment) in bottom sediments at permanent sampling sites of the Rybinsk Reservoir in ice-free periods of 2009-2014. Sites: $a$-Koprino; $\sigma$ - Mologa; $\boldsymbol{c}$ - Navolok; 2 - Izmailovo; $\partial$ - Srednyi Dvor; $e$ - Breytovo

повторяется из года в год, отражая своеобразие биотопов (рис. 3).

Количество осадочных пигментов в 3онах илонакопления согласуется с концентрацией хлорофилла в воде. В исследуемые годы содержание хлорофилла в водной толще достоверно коррелирует с концентрацией осадочных пигментов (Хл+Ф, мкг/г сухого осадка) на участках илонакопления $(r=0,31-$ $0,53 ; P<0,05 ; n=51)$. Наиболее тесная связь $\left(R^{2}=0,57\right)$ установлена между среднегодовыми для станций концентрациями хлорофилла

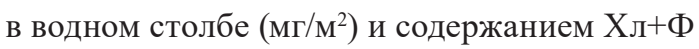

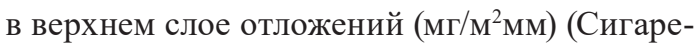
ва и др., 2016).

Межгодовая динамика содержания осадочных пигментов в зонах формирования илов, проанализированная по данным вертикального распределения в кернах и в поверхностном слое отложений, различается на станциях, что свидетельствует о преимущественном влиянии локальных условий на накопление и сохранение осевшей взвеси (Sigareva et al., 2013; Сигарева и др., 2016). Ди- 
Таблица 3. Содержание хлорофилла с феопигментами (мкг/г сухого грунта) в донных отложениях на различных станциях Рыбинского водохранилища в разные годы

Table 3. Concentration of chlorophyll and pheopigments ( $\mu \mathrm{g} / \mathrm{g}$ dry sediments) in the bottom sediments at various sites of the Rybinsk Reservoir in different years

\begin{tabular}{|c|c|c|c|c|c|c|c|}
\hline \multirow{2}{*}{ Годы } & \multirow{2}{*}{$n$} & \multicolumn{6}{|c|}{ Станция } \\
\cline { 2 - 7 } & Коприно & Молога & $\begin{array}{c}\text { Средний } \\
\text { Двор }\end{array}$ & Брейтово & Наволок & Измайлово \\
\hline $1941-2009 *$ & 253 & $44 \pm 3$ & $90 \pm 4$ & $140 \pm 5$ & $77 \pm 3$ & - & - \\
2009 & 52 & $81 \pm 9$ & $139 \pm 9$ & $161 \pm 24$ & $83 \pm 23$ & $49 \pm 18$ & $14 \pm 6$ \\
2010 & 53 & $95 \pm 8$ & $123 \pm 13$ & $172 \pm 33$ & $139 \pm 29$ & $20 \pm 10$ & $19 \pm 11$ \\
2011 & 54 & $161 \pm 14$ & $252 \pm 43$ & $268 \pm 33$ & $202 \pm 9$ & $16 \pm 8$ & $12 \pm 12$ \\
2012 & 54 & $134 \pm 21$ & $175 \pm 23$ & $299 \pm 33$ & $246 \pm 46$ & $4 \pm 1$ & $3 \pm 1$ \\
2013 & 60 & $103 \pm 10$ & $204 \pm 17$ & $296 \pm 16$ & $231 \pm 15$ & $28 \pm 13$ & $3 \pm 1$ \\
2014 & 34 & $170 \pm 19$ & $190 \pm 18$ & $231 \pm 44$ & $268 \pm 20$ & $4 \pm 1$ & $4 \pm 1$ \\
\hline
\end{tabular}

Примечание: * - средние концентрации пигментов в кернах по: (Sigareva et al., 2013), остальные - средние за безледный период на станциях в верхнем слое отложений, прочерк - отсутствие данных, $n$ - число наблюдений.

намика концентраций Хл+Ф за время существования водохранилища (с 1941 по 2014 г.) характеризовалась периодическими подъемами и спадами с тенденцией к увеличению их уровня. При этом в год с аномально жарким летом (2010 г.) концентрации пигментов в донных отложениях, как и в планктоне, не достигали самых высоких значений (табл. 3). Заметное возрастание концентраций Хл+Ф произошло в 2011-2014 гг., которые характеризовались повышенной температурой в период открытой воды.

Среднее для водохранилища содержание растительных пигментов (Хл+Ф) в донных отложениях, рассчитанное с учетом площадей грунтов разного типа, с 2009 по 2014 г. увеличилось почти в 2 раза - от $26,6 \pm 7,6$ до $51,3 \pm 11,4$ мкг/г сухого грунта. Такие концентрации соответствуют мезотрофии, а в последние годы они приблизились к значениям эвтрофной категории (60-120 мкг/г сухого грунта по: Möller, Scharf, 1986). Несмотря на возрастание концентраций растительных пигментов, содержание Хл+Ф в годовом слое донных отложений, пересчитанное на условную биомассу водорослей, составляет небольшую долю (<1%) от первичной продукции фитопланктона водохранилища (Сигарева, 2012; Sigareva, Timofeeva, 2011, 2014), что дает основание считать утилизацию новообразованного органического вещества в трофических сетях достаточно полной.

В 2004-2013 гг. средняя за вегетационный период численность зоопланктона $\left(N_{\text {зоо }}\right)$ сильно варьировала год от года (табл. 4). Межгодовые вариации $N_{\text {зоо }}$ определялись уровнем развития микропланктона (Rotifera) и меропланктона (велигеры Dreissenidae). Заметный подъем численности коловраток и, соответственно, пиковой $N_{\text {зоо }}$ зарегистрирован в 2009-2011 гг. Количество ракообразных было наибольшим (>70 тыс. экз/ $\mathrm{M}^{3}$ ) в аномально жарком 2010 г. и последующих теплых 2011 и 2013 гг. Обилие велигеров дрейссенид снизилось в три раза (<6 тыс. экз/ $\left.\mathbf{M}^{3}\right)$ после летнего замора 2010 г. За период 1956-2009 гг. не выявлено направленных изменений $N_{\text {зоо }}$ водохранилища (Лазарева, 2010). Также не отмечено достоверных отличий современной $N_{\text {зоо }}$ $\left(105 \pm 6\right.$ тыс. экз $\left./ \mathrm{M}^{3}\right)$ по сравнению с таковой 
Таблица 4. Средние численность и биомасса крупных таксонов зоопланктона и меропланктона в пелагиали Рыбинского водохранилища в 2004-2013 гг. (стандартные станции, $n=483$ )

Table 4. The average abundance and biomass of major taxa of zooplankton and meroplankton in pelagic zone of the Rybinsk Reservoir in 2004-2013 (standard sites, $n=483$ )

\begin{tabular}{|c|c|c|c|c|c|c|c|c|}
\hline \multirow{2}{*}{ Год } & \multicolumn{4}{|c|}{ Численность, тыс. экз/м³ } & \multicolumn{4}{|c|}{ Биомасса, мг/м ${ }^{3}$} \\
\hline & Rot & Clad & Cop & Vel & Rot & Clad & Cop & Vel \\
\hline 2004 & $9 \pm 1$ & $10 \pm 2$ & $26 \pm 3$ & $6 \pm 2$ & $16 \pm 3$ & $673 \pm 112$ & $270 \pm 33$ & $6 \pm 2$ \\
\hline 2005 & $64 \pm 23$ & $13 \pm 3$ & $35 \pm 6$ & $11 \pm 3$ & $383 \pm 170$ & $430 \pm 105$ & $328 \pm 69$ & $15 \pm 6$ \\
\hline 2006 & $51 \pm 17$ & $13 \pm 2$ & $26 \pm 3$ & $34 \pm 14$ & $145 \pm 44$ & $638 \pm 130$ & $227 \pm 27$ & $33 \pm 15$ \\
\hline 2007 & $38 \pm 8$ & $9 \pm 2$ & $28 \pm 3$ & $22 \pm 7$ & $98 \pm 29$ & $372 \pm 91$ & $262 \pm 31$ & $24 \pm 8$ \\
\hline 2008 & $46 \pm 12$ & $7 \pm 2$ & $25 \pm 3$ & $11 \pm 3$ & $127 \pm 43$ & $323 \pm 69$ & $196 \pm 28$ & $9 \pm 3$ \\
\hline 2009 & $80 \pm 18$ & $14 \pm 3$ & $31 \pm 5$ & $13 \pm 5$ & $179 \pm 34$ & $375 \pm 68$ & $255 \pm 43$ & $11 \pm 4$ \\
\hline 2010 & $86 \pm 18$ & $26 \pm 5$ & $46 \pm 6$ & $<2$ & $232 \pm 56$ & $652 \pm 85$ & $461 \pm 52$ & $<2$ \\
\hline 2011 & $87 \pm 15$ & $25 \pm 4$ & $49 \pm 5$ & $6 \pm 2$ & $235 \pm 80$ & $705 \pm 98$ & $574 \pm 58$ & $7 \pm 2$ \\
\hline 2012 & $30 \pm 8$ & $7 \pm 1$ & $17 \pm 2$ & $5 \pm 1$ & $102 \pm 53$ & $342 \pm 48$ & $213 \pm 31$ & $5 \pm 2$ \\
\hline 2013 & $64 \pm 9$ & $18 \pm 3$ & $64 \pm 6$ & $2 \pm 1$ & $145 \pm 47$ & $668 \pm 109$ & $602 \pm 55$ & $3 \pm 1$ \\
\hline Среднее & $56 \pm 8$ & $14 \pm 2$ & $35 \pm 4$ & $11 \pm 3$ & $166 \pm 32$ & $518 \pm 51$ & $339 \pm 48$ & $11 \pm 3$ \\
\hline
\end{tabular}

Примечание: Rot - Rotifera, Clad - Cladocera, Cop - Copepoda, Vel - Veliger Dreissenidae.

$(86 \pm 14$ тыс. экз/M3) до 1976 г. (Лазарева, Соколова, 2013).

В новом веке выявлена тенденция к смещению сроков фенологических событий сезонного цикла ракообразных, для некоторых (Daphnia galeata Sars) установлен достоверный сдвиг сроков на 1-2 нед. относительно 1960-1970-х гг. (Лазарева, Соколова, 2013). Направленность изменения структуры зоопланктона определялась непропорциональным ростом численности копепод (в 1,8 раза) и их доли (на $14 \%$ в в сообществе, подобное отмечено для западно-европейских озер (Wagner, Adrian, 2009). К 2010 г. в три раза увеличилась численность крупных (длина тела 0,6-1,8 мм) фильтраторов Cladocera (роды Bosmina и Daphnia). В совокупности с высоким обилием циклопоидных копепод это привело к изменению сезонной динамики биомассы сообщества $\left(B_{3 о 0}\right)$, появлению мощного второго летнего пика в июле-августе (Lazareva, Sokolova, 2015). В 1950-х годах, напротив, в середине лета наблюдали продолжительную депрес- сию $\left(<1 \quad \Gamma / \mathrm{M}^{3}\right)$ биомассы зоопланктона (Рыбинское водохранилище..., 1972). Средняя за май-октябрь $B_{3 о}$ в пелагиали водоема составила $1,0 \pm 0,05 \Gamma / \mathrm{M}^{3}$, многолетние ее вариации определялись обилием ракообразных, особенно кладоцер (табл. 4). Установлена положительная корреляция $(r=0,70-0,82, p<0,05)$ биомассы зоопланктона, численности кладоцер и копепод с Т воды водохранилища.

Появление придонного дефицита растворенного $\mathrm{O}_{2}$ в период массового развития цианобактерий привело к изменению вертикального распределения зоопланктона. В дневное время в центре водохранилища $\left(\mathrm{O}_{2}>6\right.$ мг/л) обычны скопления фильтраторов (род Daphnia) в слое 5-6 м над дном водохранилища (75 \% численности вида под $1 \mathrm{~m}^{2}$ ) под основной массой водорослей (рис. 4a), при обилии D. galeata выше 200 тыс. экз/ $\mathrm{M}^{2}$. Миграция глубже 5 м в меньшей степени выражена у циклопоидных копепод. На участках водоема, где регистрировали снижение $\mathrm{O}_{2}$ менее 5 мг/л в слое до 4 м над дном (у дна 


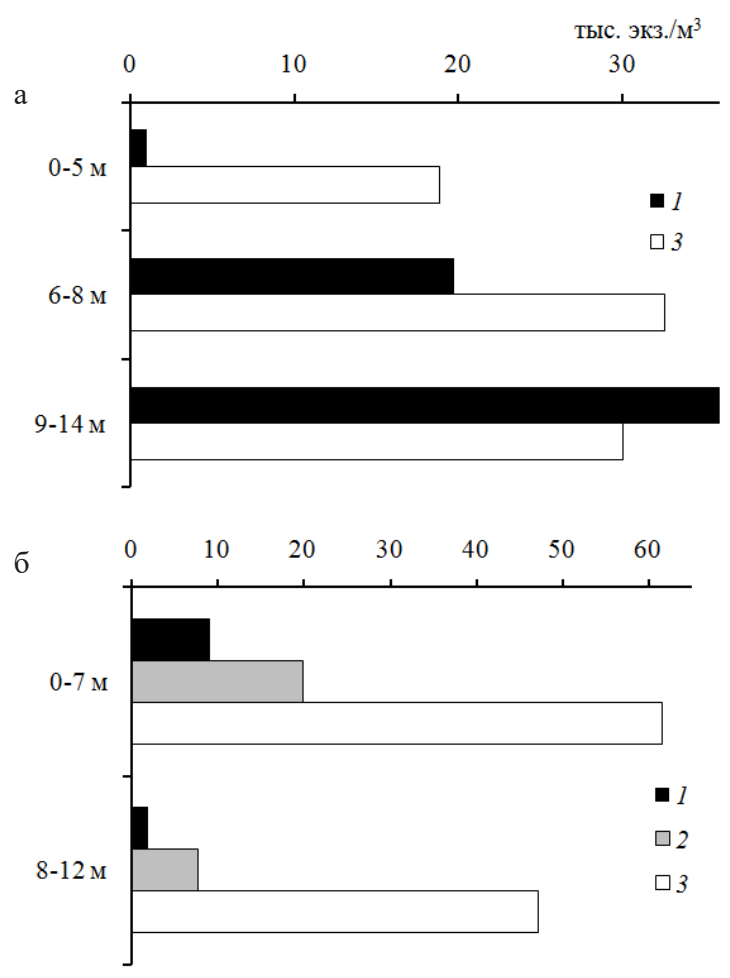

Рис. 4. Вертикальное распределение численности доминантных видов зоопланктона в пелагиали Рыбинского водохранилища в норме (а) и в условиях придонного дефицита растворенного кислорода (б). 1 -Daphnia galeata, 2 - Eudiaptomus gracilis et graciloides, 3 - Mesocyclops leuckarti

Fig. 4. Vertical distribution of abundance of zooplankton dominant species in pelagic zone of the Rybinsk Reservoir under normal conditions (a) and dissolved oxygen deficit near bottom (б). 1 - Daphnia galeata, 2 - Eudiaptomus gracilis et graciloides, 3 - Mesocyclops leuckarti

1,2-3,6 мг/л), отмечен подъем ракообразных в верхний 7-метровый горизонт, особенно фильтраторов Daphnia ( 90 \% численности) и Eudiaptomus ( $>0 \%$ численности) (рис. 46$)$. Общее количество дафний $\left(<80\right.$ тыс. экз/ $\left.\mathrm{M}^{2}\right)$ снижалось более чем вдвое. Придонный дефицит $\mathrm{O}_{2}$ приводил к миграции фильтраторов в верхний слой воды водохранилища, в котором их жизнедеятельность угнетали цианобактерии (биомасса $0,5-1,8$ г/м³). Формирование летнего дефицита растворенного кислорода служит важнейшим следствием потепления (Лазарева, 2014; Wilhelm, Adrian, 2008), однако его влияние на вертикальное распределение и обилие фильтраторов в крупных водохранилищах зарегистрировано впервые.

\section{Обсуждение результатов}

Как показали исследования на озерах и реках (Трифонова, 1986; Охапкин, 1997), по мере увеличения трофии вод наблюдается постепенное нарастание числа пиков биомассы фитопланктона и замещение весеннего максимума (олиготрофный тип) на летний (эвтрофный тип). То же самое прослеживалось и в многолетнем изменении сезонной динамики биомассы фитопланктона Рыбинского водохранилища. Эти изменения были сопряжены со сроками (середина 1970-х гг.) начала повышения температуры воды и увеличения количества осадков (Второй оценочный..., 2014). Хотя суммарная биомасса фитопланктона в последние десятилетия снижалась, но, как по- 
казали литературные (Литвинов и др., 2014) и наши данные, концентрация хлорофилла в воде, наоборот, увеличивалась. Такое несоответствие может объясняться уменьшением размера клеток фитопланктона, что подтверждалось многолетним достоверным увеличением соотношения численности и биомассы. Увеличение обилия мелкоразмерных видов фитопланктона наблюдалось при увеличении трофии озер (Михеева, 1992). Поскольку мелкие клетки водорослей более фотосинтетически активны (Гутельмахер, 1986), то это могло способствовать росту концентрации хлорофилла и первичной продукции в Рыбинском водохранилище. Увеличение количества атмосферных осадков с середины 1970-х гг. (Второй оценочный..., 2014), повышение содержания аллохтонного органического вещества, цветности вод в Рыбинском водохранилище (Лазарева, Соколова, 2013; Степанова, 2015) и снижение их прозрачности создавали условия для конкурентного преимущества жгутиковых форм (криптофитовых и золотистых водорослей), способных как к автотрофии, так и фаготрофии (Корнева, 2015; Korneva, Solovyeva, 2017). Миксотрофия обычно развивается в условиях слабой биодоступности минеральных питательных веществ и светового лимитирования. При этом дополнительным источником питания становятся бактерии (Olrik, 1998), что обеспечивает более эффективный перенос энергии с меньшим отвлечением на детритный путь (Stewart, Wetzel, 1986). Увеличение минерализации в Рыбинском водохранилище (Законнова, Литвинов, 2009) способствовало проникновению и распространению эвригалинных аллохтонных видов диатомовых водорослей (Корнева, 2015). Полученные статистические связи между суммарной биомассой фитопланктона и цианобактерий с гидрофизическим показателями свидетельствовали о четкой сопряженности их многолетнего изменения с уровенным и температурным режимами водоема, как интегральными показателями климатических изменений. Обилие цианобактерий обычно увеличивается с ростом температуры воды и трофии водоемов (Paerl, Huisman, 2009). Помимо увеличения пропорции цианобактерий и миксотрофных видов в биомассе фитопланктона наблюдалось снижение числа диазотрофных видов (Корнева, 2015). Все это свидетельствует о том, что климатические изменения приводят к трансформации соотношения функциональных групп фитопланктона.

Среднее содержание хлорофилла в водной толще водохранилища, отражающее уровень трофии водоема (Винберг, 1960 и др.), в 2009-2014 гг. представлено величинами, которые характерны для вод умеренно эвтрофного (10-15 мкг/л) и эвтрофного (15-30 мкг/л) типа. Как и в других водохранилищах Волги (Kopylov et al., 2012), оно стало выше, чем в предшествующие периоды. Это увеличение происходит высокими темпами, так как ежегодный прирост $\Sigma Х$ л, который аппроксимируется уравнением $y=4,79 x\left(R^{2}=0,91, F=56,5\right)$, вчетверо выше, чем в 1969-1984 гг. Параллельно со среднесезонной концентрацией $\Sigma$ Хл увеличивается ее дисперсия $(r=0,88, p=0,02)$, что отражает снижение устойчивости системы. В сезонной динамике $\Sigma$ Хл его летний максимум (45,6 2,2,0 мкг/л) увеличился в 1,4 раза по сравнению с аналогичным показателем 1969-1984 гг. (Минеева, 2004) и стал существенно преобладать над весенним. Выросло содержание хлорофилла цианобактерий, что особенно наглядно прослеживается в 2013 г. Возросшие концентрации и одновершинная кривая $\Sigma$ Хл с продолжительным летним подъемом служат признаком повышения уровня трофии водохранилища. 
В год с аномально жарким летом (2010 г.) концентрации пигментов как в воде, так и в донных отложениях не достигали самых высоких значений, как можно было бы ожидать. Очевидное повышение концентраций произошло в последующие 2011 и 2013 гг. Вероятной причиной, ограничивающей развитие растительных сообществ в 2010 г., можно считать продолжительную штилевую погоду (снижение гидродинамической активности), препятствующую поступлению биогенных элементов со дна в воду. Ранее предполагалось, что в 2010 г. благоприятные условия (в виде накопления доступных для водорослей элементов минерального питания) для повышения продукционных показателей только создавались (Сигарева, Тимофеева, 2012; Sigareva, Timofeeva, 2014), а их реализация происходила позднее. Настоящая работа подтверждает правильность этого предположения. Кроме этого, анализ температурной зависимости позволил выявить диапазон температуры с максимальными концентрациями хлорофилла цианобактерий, который составил $20-25{ }^{\circ} \mathrm{C}$ (Минеева, 2016). При повышении температуры содержание Хл но, и объясняет невысокое общее содержание хлорофилла в водохранилище летом 2010 г. при экстремальном прогреве, не свойственном водоемам умеренных широт.

Тесная связь между содержанием пигментов в воде и донных отложениях отражает взаимодействие новообразования и деструкции органического вещества. Тренды многолетней динамики хлорофилла в воде согласуются с таковыми в отложениях в зонах илонакопления (Сигарева и др., 2016). В условиях интенсивного потепления увеличение концентрации осадочных пигментов свидетельствует о повышении продуктивности экосистемы водохранилища в пределах мезотрофного состояния. Однако в дальней- шем следует ожидать очередное уменьшение значений всех трофических показателей, поскольку динамике продукционных процессов в водохранилище свойственна цикличность. Именно цикличность показателей первичной продукции, отмечаемая в связи с климатическими условиями, способствует сохранению устойчивого функционирования экосистемы водохранилища. Устойчивость экосистемы поддерживается сменой видового состава и динамикой структуры биологических сообществ, в частности фито- и зоопланктона.

В озерах увеличение Т воды и продолжительности вегетационного периода обычно сопровождается ростом количества зоопланктона, особенно видов рода Daphnia (Shindler et al., 2005), то же отмечено для водохранилищ Волги (Kopylov et al., 2012). В Рыбинском водохранилище с 1970-х гг. по 2010 г. более чем вдвое возросла численность большинства доминантных видов зоопланктона, биомасса и продукция за вегетационный период увеличились в 1,7 раза по сравнению с периодом до потепления (Лазарева, Соколова, 2013; Lazareva, Sokolova, 2015). В 2004-2010 гг. уровень суточной продукции сообщества $(0,34-$ 0,52 ккал/м²) был близок к наблюдаемому в эвтрофных водоемах (Lazareva, Sokolova, 2015), тогда как в 1960-1970-х гг. (0,21 ккал/м²) соответствовал наблюдавшемуся в олиготрофных и мезотрофных озерах (Владимирова, 1974). В 2004-2013 гг. значения индексов трофности по зоопланктону $E$ и $E / O-(1,3-3,0)$ на всей акватории водохранилища соответствовали уровню эвтрофных вод. В речных плесах число индикаторов эвтрофии было выше в $1,6-1,8$ раза, показатели $E$ и $E / O$ в $1,3-2$ раза, а встречаемость коловраток рода Brachionus в 3-6 раз по сравнению с Главным плесом водохранилища. В целом, по зоопланктону Главный плес менее эвтрофирован (умеренно эвтрофный), чем речные, которые можно от- 
нести к эвтрофным, особенно эвтрофированы Волжский и Шекснинский. Таким образом, потепление климата способствовало росту обилия и продуктивности зоопланктона, а также эвтрофированию экосистемы водохранилища.

Пошаговый регрессионный анализ влияния на характеристики зоопланктона ( $B_{30 о}$, численность Cladocera, Copepoda и Rotifera) показателей развития фитопланктона (концентрация в воде хлорофилла и биомасса цианобактерий, диатомовых и зеленых водорослей) и Т воды свидетельствовал о том, что в период 2009-2013 гг. наиболее важными факторами, стимулирующими развитие пелагического зоопланктона водохранилища, являлись Т воды $(F=11-22)$ и обеспеченность доступной пищей (зеленые и диатомовые водоросли, $F=6-10)$. Эти факторы определяли $\sim 40 \%$ дисперсии биомассы зоопланктона и $>30 \%$ численности основных групп фильтраторов (Cladocera, Rotifera). Значимое отрицательное влияние на консументов $(F=5-6)$ оказывало массовое развитие цианобактерий (в основном роды Aphanizomenon и Microcystis), которое определяло 7-9 \% изменчивости характеристик зоопланктона. Эти водоросли образуют крупные колонии (>300 мкм), которые недоступны фильтраторам. Размеры частиц, потребляемых фильтраторами зоопланктона, составляют 5-30 мкм (Lampert et al., 1986). К тому же в большом количестве цианобактерии мешают нормальной работе фильтрующего аппарата ракообразных. При достаточном содержании в воде растворенного $\mathrm{O}_{2}$ ракообразные-фильтраторы концентрируются ниже основной массы водорослей (глубже 5-7 м) и у дна водоема (рис. 4). В водохранилищах Волги отмечено достоверное снижение в три раза численности Daphnia galeata в скоплениях водорослей (Хл $a>40$ мкг/л), среди которых преобладали цианобактерии (Lazareva et al., 2014).

\section{Заключение}

В ходе изменения климата, последствия которого в Рыбинском водохранилище прежде всего выражались в повышении температуры, минерализации, цветности воды и снижении прозрачности, ухудшении кислородного режима, происходило изменение таксономической и размерной структуры фитопланктона: увеличение в общей биомассе пропорции цианобактерий, миксотрофных фитофлагеллят, появление и натурализация солоновато-водных диатомовых, уменьшение размерности клеток, а также изменение хода сезонной динамики биомассы: от преобладания весеннего максимума диатомовых водорослей к доминированию летнего пика цианобактерий.

В 2009-2014 гг. в Рыбинском водохранилище сохранились основные элементы сезонной динамики хлорофилла в толще воды, наблюдаемые ранее. Однако в сравнении с предшествующими данными по содержанию хлорофилла цианобактерий наблюдалось увеличение периода их вегетации. Кроме того, отмечен рост встречаемости высоких величин концентраций хлорофилла, типичных для эвтрофных и высокоэвтрофных вод. Подъем Хл начался на следующий год после аномально высоких температур.

В условиях интенсивного потепления климата динамика растительных пигментов в донных отложениях сохраняет свойственную водохранилищу специфичность. Тесная связь между содержанием пигментов в планктоне и поверхностном слое илов отражает зависимость между пелагической и донной подсистемами. Цикличность содержания осадочных пигментов, отмечаемая в многолетнем аспекте, дает основание считать, что экосистема водохранилища функционирует устойчиво, несмотря на глобальные изменения климата. 
В зоопланктоне выявлено увеличение факторами, стимулирующими развитие зоообилия циклопоидных копепод, существенный рост биомассы и продукции, а также смещение сроков фенологических событий сезонного цикла доминантных видов ракообразных на 1-2 нед. относительно 1960-1970-х гг. и, как следствие, изменение сезонной динамики обилия зоопланктона. По показателям зоопланктона выявлено усиление эвтрофирования экосистемы водохранилища. Основными планктона, явились Т воды и количество доступной пищи (зеленые и диатомовые водоросли). Негативное биотическое воздействие на сообщество вызывало массовое развитие цианобактерий. После 2010 г. локальный дефицит растворенного кислорода у дна водоема стал дополнительным фактором, влияющим на вертикальное распределение и снижающим обилие ракообразных-фильтраторов.

\section{Список литературы}

Андроникова И.Н. (1996) Структурно-функциональная организация зоопланктона озерных экосистем. СПб., Наука, 189 с. [Andronikova I.N. (1996) Structural and functional organization of zooplankton in lake ecosystems of different trophic status. St-Petersburg, Nauka, 189 p. (in Russian)]

Винберг Г.Г. (1960) Первичная продукция водоемов. Минск, АН БССР, 329 с. [Vinberg G.G. (1960) Primary production of the basins. Minsk, AN BSSR, 329 p. (in Russian)]

Владимирова Т.М. (1974) Продукция зоопланктона Рыбинского водохранилища. Биология и продуктивность пресноводных беспозвоночных. Вайнштейн В.А. (ред.) Л., Наука, c. 37-42 [Vladimirova T.M. (1974) Zooplankton production in the Rybinsk Reservoir. The biology and productivity of freshwater invertebrates. Weinstein V.A. (ed.) Leningrad, Nauka, p. 37-42 (in Russian)]

Второй оченочный доклад Росгидромета об изменениях климата и их последствиях на территории Российской Федераџии. Общее резюме (2014) М., Росгидромет, 61 с. [Sесоnd assessment Rosgydromet's report of climate change and its consequences on the territory of the Russian Federation. Executive summary (2014) Moscow, Rosgydromet, 61 p. (in Russian)]

Гаевский Н.А., Шатров И.Ю., Гольд В.М. (1993) Флуоресцентный анализ пигментов фитопланктона. Методические вопросы изучения первичной продукиии внутренних водоемов. Пырина И.Л. (ред.) СПб., Гидрометеоиздат, с. 101-109 [Gaevsky N.A., Shatrov I.Yu., Gol'd V.M. (1993) Fluorescent analyses of pigments in phytoplankton. Methodical problems of primary production study in inland waters. Pyrina I.L. (ed.) St-Petersburg, Hydrometeoizdat, p. 101-109 (in Russian)]

Гольд В.М., Гаевский Н.А., Шатров И.Ю., Попельницкий В.А., Рыбцов С.А. (1986) Опыт использования флуоресценции для дифференциальной оценки содержания хлорофилла а у планктонных водорослей. Гидробиологический журнал, 22 (3): 80-85 [Gol'd V.M., Gaevsky N.A., Shatrov I.Yu., Popel'nitsky V.A., Rybtsov S.A. (1986) Practice in the use of fluorescence for different estimation of chlorophyll content in plankton algae. Hydrobiological Journal [Gydrobiologitcheskiy zhurnal], 22 (3): 80-85 (in Russian)]

Гутельмахер Б.Г. (1986) Метаболизм планктона как единого иелого. Л., Наука, 155 с. [Gutelmacher B.G. (1986) Metabolism of plankton as a whole. Leningrad, Nauka, 155 p. (in Russian)]

Законнова А.В., Литвинов А.С. (2009) Солевой состав воды Рыбинского водохранилища и его многолетние изменения. Гидробиологический журнал, 45 (2): 96-110 [Zakonnova A.V., 
Litvinov A.S. (2009) The salt composition of water of the Rybinsk Reservoir and its long-term changes. Hydrobiological Journal [Gydrobiologitcheskiy zhurnal], 45 (2): 96-110 (in Russian)]

Законнова А.В., Литвинов А.С. (2016) Многолетние изменения гидроклиматического режима Рыбинского водохранилища. Гидролого-гидрохимические исследования водоемов бассейна Волги. Ярославль, Филигрань, с. 16-22 [Zakonnova A.V., Litvinov A.S. (2016) Long-term changes in the hydroclimatic regime of the Rybinsk Reservoir. Hydrological and hydrochemical investigations catchment area of Volga. Yaroslavl, Filigran, p. 16-22 (in Russian)]

Корнева Л.Г. (2015) Фитопланктон водохранилищ бассейна Волги. Кострома, Костромской печатный дом, 284 c. [Korneva L.G. (2015) Phytoplankton of Volga River basin reservoirs. Kostroma, Kostroma printing house, 284 p. (in Russian)]

Лазарева В.И. (2010) Структура и динамика зоопланктона Рыбинского водохранилища. М., Товарищество научных изданий КМК, 183 с. [Lazareva V.I. (2010) Zooplankton structure and dynamics in the Rybinsk Reservoir. Moscow, Tovarischestvo nauchnyh izdanii KMK, 183 p.]

Лазарева В.И. (2014) Потепление климата и его влияние на зоопланктон водохранилищ Волги. Экологический мониторинг. Часть VIII. Современные проблемы мониторинга пресноводных экосистем. Гелашвили Д.Б., Шурганова Г.В. (ред.) Нижний Новгород, Нижегородский ун-т, с. 182-208 [Lazareva V.I. (2014) Climate warming and its impact on zooplankton of the Volga Reservoirs. Ecological Monitoring. Part VIII. Modern freshwater ecosystems monitoring problems: a tutorial. Gelashvili D.B., Shurganova G.V. (eds.) Nizhny Novgorod, Nizhny Novgorod Univ., p. 182208 (in Russian)]

Лазарева В.И., Соколова Е.А. (2013) Динамика и фенология зоопланктона крупного равнинного водохранилища: отклик на изменение климата. Усnехи современной биологии, 133 (6): 564-574 [Lazareva V.I., Sokolova E.A. (2013) Dynamics and phenology of zooplankton in a large plain reservoir: a response to climate changes. Advances in Modern Biology [Uspekhi sovremennoy biologii], 133 (6): 564-574 (in Russian)]

Литвинов А.С., Пырина И.Л., Законнова А.В. (2014) Термический режим и продуктивность фитопланктона Рыбинского водохранилища в условиях изменения климата. Вода: химия и экология, 12: 108-112 [Litvinov A.S., Pyrina I.L., Zakonnova A.V. (2014) Thermal regime and productivity of phytoplankton in the Rybinsk Reservoir under climate change. Water: Chemistry and Ecology [Voda: khimiya i ecologiya], 12: 108-112 (in Russian)]

Методика изучения биогеоценозов внутренних водоемов (1975) Мордухай-Болтовской Ф.Д. (ред.) М., Наука, 240 с. [Methods of study of inland waters ecosystems (1975) MordukhaiBoltovskoy F.D. (ed.) Moscow, Nauka, 240 p. (in Russian)]

Минеева Н.М. (2004) Растительные пигменты в воде волжских водохранилищ.. М., Наука, 158 c. [Mineeva N.M. (2004) Plant pigments in waters of the Volga River reservoirs. Moscow, Nauka, 158 p. (in Russian)]

Минеева Н.М. (2016) Сезонная и межгодовая динамика хлорофилла в планктоне Рыбинского водохранилища по данным флуоресцентной диагностики. Экология, морфология и систематика водных растений. Бобров А.А. (ред.) Ярославль, Филигрань, с. $75-93$ [Mineeva N.M. (2016) Study of seasonal and interannual dynamics of chlorophyll in plankton of the Rybinsk Reservoir based on fluorescence diagnosis. Ecology, morphology and systematics of aquatic plants. Bobrov A.A. (ed.) Yaroslavl, Filigran, p. 75-93 (in Russian)] 
Михеева Т.М. (1992) Структура и функционирование фитопланктона при эвтрофировании вод. Автореф. дисс. ... д-ра биол. наук. Минск, 63 с. [Mikheyeva T.M (1992) Structure and functioning of phytoplankton at the water eutrophication. Thesis abstract of Dissertation Doctor Sciences. Minsk, 63 p. (in Russian)]

Мяэметс А.Х. (1980) Изменения зоопланктона. Антропогенное воздействие на малье озеpa. Коплан-Дикс И.С., Стравинская Е.А. (ред.) Л., Наука, с. 54-64 [Myaemets A. (1980) Changes in zooplankton. Anthropogenic impact on small lakes. Koplan-Dix I.S., Stravinskaya E.A. (eds.) Leningrad, Nauka, p. 54-64 (in Russian)]

Нестеров Е.С. (2013) Североатлантическое колебание: атмосфера и океан. М., Триада, 144 c. [Nesterov E.S. (2013) North Atlantic oscillation: atmosphere and ocean. Moscow, Triada, 144 p. (in Russian)]

Охапкин А.Г. (1997) Структура и сукиессия фитопланктона при зарегулировании речного стока. Автореф. дисс. ... д-ра биол. наук. Спб., 48 с. [Okhapkin A.G (1997) Structure and succession of phytoplankton at the over-regulation of river flow. Abstract of Dissertation ... Doctor of Sciences. St. Petersburg, 48 p. (in Russian)]

Романенко В.И. (1985) Микробиологические процессы продукциии и деструкции органического вещеества во внутренних водоемах. Л., Наука, 295 с. [Romanenko V.I. (1985) Microbial processes of production and destruction of organic matter in inland aquatic environments. Leningrad, Nauka, 295 p. (in Russian)]

Рыбинское водохранилище и его жизнь (1972) Кузин Б.С. (ред.) Л., Наука, 364 с. [Rybinsk reservoir and its life (1972) Kuzin B.S. (ed.) Leningrad, Nauka, 364 p. (in Russian)]

Сигарева Л.Е. (2012) Хлорофилл в донных отложениях волжских водоемов. М., КМК, 217 с. [Sigareva L.E. (2012) Chlorophyll in bottom sediments of the Volga water bodies. Moscow, KMK, 217 p. (in Russian)]

Сигарева Л.Е., Пырина И.Л., Тимофеева Н.А. (2016) Межгодовая динамика растительных пигментов в воде и донных отложениях Рыбинского водохранилища. Экология, морфология и систематика водных растений. Бобров А.А. (ред.) Ярославль, Филигрань, с. 119-130 [Sigareva L.E., Pyrina I.L., Timofeeva N.A. (2016) Interannual dynamics of chlorophyll content in plankton and bottom sediments of the Rybinsk reservoir. Ecology, Morphology and Systematics of Aquatic Plants. Bobrov A.A. (ed.) Yaroslavl, Filigran, p. 119-130 (in Russian)]

Сигарева Л.Е., Тимофеева Н.А. (2012) Содержание растительных пигментов в отложениях Рыбинского водохранилища в год с экстремально жарким летом (2010). Поволжский экологический журнал, 4: 415-425 [Sigareva L.E., Timofeeva N.A. (2012) The content of plant pigments in the sediments of the Rybinsk Reservoir in a year with an extremely hot summer (2010). Volga Region Ecological Journal [Povolzhskiy ekologicheskiy zhurnal], 4: 415-425 (in Russian)]

Степанова И.Э. (2015) Характеристики органического вещества в Рыбинском водохранилище на современном этапе. Вода: химия и экология, 10: 3-10 [Stepanova I.E. (2015) Characteristics of organic matter in the Rybinsk Reservoir on the modern stage. Water: chemistry and ecology [Voda: khimiya i ecologiya], 10: 3-10 (in Russian)]

Трифонова И.С. (1986) Сезонная и основная сукцессия озерного фитопланктона. Гидробиологический журнал, 22 (3): 21-28 [Trifonova I.S. (1986) Seasonal and main lake phytoplankton succession. Hydrobiological Journal [Gydrobiologitcheskyi zhurnal], 22 (3): 21-28 (in Russian)]

$$
-177-
$$


Экологические проблемы Верхней Волги (2001) Копылов А.И (ред.) Ярославль, Ярославский гос. техн. ун-т, 427 с. [Ecological problems of the Upper Volga (2001) Kopylov A.I. (ed.) Yaroslavl, Yaroslavl State Technical University, 427 p. (in Russian)]

Adrian R., O’Reilly C.M., Zagareze H., Baines S.B., Hessen D.O., Keller W., Livingstone D.M., Sommaruga R., Straile D., Van Donk E., Weyhenmeyer G.A., Winder M. (2009) Lakes as sentinels of climate change. Limnology and Oceanography, 54 (6, part 2): 2283-2297

Hakkari L. (1972) Zooplankton species as indicators of environment. Aqua Fennica: 46-54

Kopylov A.I., Lazareva V.I., Mineeva N.M., Maslennikova T.S., Stroinov Ya.V. (2012) Influence of anomalous high water temperatures on the development of the plankton community in the Middle Volga reservoirs in summer 2010. Doclady Biological Sciences, 442: 11-13

Korneva L.G., Solovyeva V.V. (2017) Golden algae (Chrysophyta) in plankton of the Volga river reservoirs: taxonomic structure, dynamics of diversity and abundance. Inland Water Biology, 10 (2): $168-175$

Lampert W., Fleckner W., Rai H., Taylor B.E. (1986) Phytoplankton control by grazing zooplankton: a study on the spring clear-water phase. Limnology and Oceanography, 31: 478-490

Lazareva V.I., Mineeva N.M., Zhdanova S.M. (2014) Spatial distribution of plankton from the Upper and Middle Volga reservoirs in years with different thermal conditions. Biology Bulletin, 41 (10): 869-878

Lazareva V.I., Sokolova E.A. (2015) Metazooplankton of the plain reservoir during climate warming: biomass and production. Inland Water Biology, 8 (3): 250-258

Lorenzen C.J. (1967) Determination of chlorophyll and phaeo-pigments: spectrophotometric equations. Limnology and Oceanography, 12 (2): 343-346

Magnuson J.J., Robertson D.M., Benson B.J., Wynne R.H., Livingstone D.M., Arai T., Assel R.A., Barry R.G., Card V., Kuusisto E., Granin N.G., Prowse T.D., Stewart K.M., Vuglinski V.S. (2000) Historical trends in lake and river ice cover in the Northern Hemisphere. Science, 289: 1743-1746

Möller W.A.A., Scharf B.W. (1986) The content of chlorophyll in the sediment of the volcanic maar lakes in the Eifel region (Germany) as an indicator for eutrophication. Hydrobiologia, 143: 327-329

Olrik K. (1998) Ecology of mixotrophic flagellates with special reference to Chrysophyceae in Danish lakes. Hydrobiologia, 369/370: 329-338

Paerl H.W., Huisman J. (2009) Climate change: a catalyst for global expansion of harmful cyanobacterial blooms. Environmental Microbiology Reports, 1 (1): 27-37

Schindler D.E., Rogers D.E., Scheuerell M.D., Abrey C.A. (2005) Effects of changing climate on zooplankton and juvenile sockeye salmon growth in southwestern Alaska. Ecology, 86: 198-209

Sigareva L.E., Timofeeva N.A. (2011) Sedimentary chlorophyll and pheopigments for monitoring of reservoir characterized by exclusively high dynamism of abiotic conditions. Chapter V. Chlorophyll: Structure, Production and Medicinal Uses. Le H., Salcedo E. (eds.) New York, Nova Science Publisher, Inc., p. 151-176

Sigareva L.E., Timofeeva N.A. (2014) The phytoplankton role in formation of bottom sediment productivity in a large reservoir in the years with different temperature conditions. Chapter VI. Phytoplankton: Biology, Classification and Environmental Impacts. Sebastia M. (ed.) New York, Nova Science Publisher, Inc., p. 161-175 
Sigareva L.E., Zakonnov V.V., Timofeeva N.A., Kasyanova V.V. (2013) Sediment pigments and silting rate as indicators of the trophic condition of the Rybinsk reservoir. Water Resources, 40 (1): 54-60

Stewart A.J., Wetzel R.G. (1986) Cryptophytes and other microflagellates as couplers in planktonic community dynamics. Archiv fur Hydrobiologie, 106 (1): 1-19

Wagner C., Adrian R. (2009) Exploring lake ecosystems: hierarchy responses to long-term change? Global Change Biology, 15: 1104-1115

Wilhelm S., Adrian R. (2008) Impact of summer warming on the thermal characteristics of a polymictic lake and consequences for oxygen, nutrients and phytoplankton. Freshwater Biology, 53: 226-237 